\title{
Location, location, location? Analysing property rents in medieval Gloucester
}

Article

Accepted Version

Casson, C. and Casson, M. (2016) Location, location, location? Analysing property rents in medieval Gloucester. The Economic History Review, 69 (2). pp. 575-599. ISSN 14680289 doi: https://doi.org/10.1111/ehr.12117 Available at https://centaur.reading.ac.uk/49601/

It is advisable to refer to the publisher's version if you intend to cite from the work. See Guidance on citing.

To link to this article DOI: http://dx.doi.org/10.1111/ehr.12117

Publisher: Wiley-Blackwell

All outputs in CentAUR are protected by Intellectual Property Rights law, including copyright law. Copyright and IPR is retained by the creators or other copyright holders. Terms and conditions for use of this material are defined in the End User Agreement.

\section{www.reading.ac.uk/centaur}

\section{CentAUR}

Central Archive at the University of Reading

Reading's research outputs online 


\title{
Location, Location, Location? Analysing Property Rents in Medieval Gloucester \\ Catherine Casson and Mark Casson
}

\begin{abstract}
Although medieval rentals have been extensively studied, few scholars have used them to analyse variations in the rents paid on individual properties within a town. It has been claimed that medieval rents did not reflect economic values or market forces, but were set according to social and political rather than economic criteria, and remained ossified at customary levels. This paper uses hedonic regression methods to test whether property rents in medieval Gloucester were influenced by classic economic factors such as the location and use of a property. It investigates both rents and local rates (landgavel), and explores the relationship between the two. It also examines spatial autocorrelation. It finds significant relationships between urban rents and property characteristics that are similar to those found in modern studies. The findings are consistent with the view that, in Gloucester at least, medieval rents were strongly influenced by classical economic factors working through a competitive urban property market.
\end{abstract}


The operation of the medieval urban property market has been identified as an important topic by a number of historians. They have explored topics including social change in households (Harding and Wright, 1995, Rees Jones, 1987), urban growth and decline (Goddard, 2004; Keene, 1985; Butcher, 1978) and the role of local institutions in shaping urban development (Baker and Holt, 2004). While all acknowledge the importance of rent levels in their work, they also refer to some of the difficulties that the medieval legal complexities pose in allowing these rent levels to be accurately assessed.

In contrast, research on agricultural rents has adopted a more statistical methodology to investigate somewhat different issues. Allen (1998), Clark (2002) and Turner, Beckett and Afton (1997) have all developed indices of agricultural rents in order to explore the origins of the Agricultural Revolution and to measure agricultural productivity growth.

This paper seeks to apply some of the quantitative techniques more commonly used to analyse agricultural rents to the analysis of urban rents by applying hedonic regression techniques to urban rents. The paper aims to consider whether variations in rent levels are due to:

- the location of the property within the town;

- the physical characteristics of the property;

- the use of the property;

- the status and occupation of the tenant; and

- the identity of the property owner.

In principle all these factors may apply simultaneously, as many properties were both places of work and places of residence, and parts of properties (rooms, workshops, etc.) were often sublet.

Rents can be estimated from various sources, but rentals are particularly useful, because they not only identify the recipient but may also indicate the location of the property, its size, the nature of any buildings, and the names of the owners and occupiers. The nature of the buildings, together with the identity of the occupier, may provide clues as to the use of the property (work, residence, stabling, etc.) and the nature of any trade carried on there. Information on different properties can be used to generate a profile of the geographical distribution of trades within a town. In addition, the street names mentioned in rentals may be indicative of concentrations of specialised trades (Langton, 1977).

Rents are usually expressed as shillings and pence paid per annum, although some rents may be paid in kind and others may be waived, or not reported because they are in arrears. Many rentals were compiled specifically to assess 'ability to pay'; e.g. the ability of property owners to contribute to the town farm (paid to the king or a local lord), or the ability of a dominant landowner to raise rents in order to enhance their income. 
Numerical information on the rents of individual properties is widely available; Table 1 lists some published urban rentals that contain sufficient information to support a statistical analysis. There were different types of rent payment, and they are not always easy to distinguish. Rentals are rarely comprehensive in their coverage of properties (e.g. they normally exclude buildings used as churches and monasteries, although they include buildings owned by churches and monasteries but used for secular purposes). Sometimes rents must be adjusted in order to maintain comparability between different properties; e.g. independent properties with a common owner may be grouped, so that the rents of constituent properties must be imputed by the researcher, or a property with multiple occupants may be subdivided, so that the individual rents must be aggregated. In general, though, it is straightforward to make such adjustments.

It has been suggested that urban rents were often ossified and did not reflect current conditions; they reflected long-forgotten circumstances at the time they were first set, and were effectively arbitrary by the time a rental was compiled [REF]. If this were true then rents would appear random, and would not be systemically related to location, ownership or use. This hypothesis will be tested in this paper.

It is possible to map distributions of rents using geographical information systems (GIS). This is not straightforward, however, because the precise locations of some medieval properties may not be known, even though their relationship to neighbouring properties may be documented. A more serious problem, however, is that the interpretation of maps remains subjective unless supported by statistical analysis, because random fluctuations in spatial data can often generate misleading patterns. Thus chi-square or other tests of significance need to be performed. But chi-square tests can themselves be misleading if they analyse one characteristic at a time without controlling for co-variation in others. The most appropriate way to control for co-variation in property characteristics is to use hedonic multiple regression.

To ensure robust results, it is necessary to validate the sample of properties involved. To disentangle the influence on rents of the location, ownership and use of the various properties, it is necessary to interpret the results carefully and to appreciate the limitations of the technique. The present case study suggests, however, that these limitations are not so great as might be supposed.

\section{II}

This paper follows a standard methodology in empirical social science whereby general theoretical principles are used to deduce hypotheses, and these hypotheses are then tested using data generated from the available evidence. In this paper the general hypotheses relate to the determinants of property rents within an urban economy. The hypotheses are derived from general economic theories of rent determination, and from the general literature on urban economics. The evidence relates to the rents on individual properties.

The paper involves a case study of Gloucester, based on a well-known 1455 rental (Gloucestershire Archives GBR/J/5/1). The rental was compiled by Robert Cole, a Canon of 
Llanthony Secunda Priory, which, together with St. Peter's Abbey (later the Cathedral), was a major landowner in Gloucester. The priory was founded in 1136, on the west bank of the River Severn just south of town, by monks who had survived the destruction of their first abbey, near Abergavenny, by Welsh rebels. John Garland was prior at the time, and Cole (ordained 1419) had been chaplain to his predecessor John Wyche (Langston, 1942, pp.1156). Little else is known about Cole, but it seems likely that he as well known in the city and had good relations with local office-holders.

The involvement of monastic orders in the property market was not unusual (Bouchard, 1991). Both the monastery and the city may have been adversely affected by a long-term trade depression at this time (Hatcher, 1996). Baker and Holt have suggested that the rental of 1455 is unusual in the cooperation that it shows been the religious house and the civic authorities at a difficult time. The roll appears to have been commissioned by the civic authorities of the town in order to systematically record the revenue that was due to the civic authorities on certain properties.

The rental contains information on over 800 properties, but there is usable information on rents for only about half of them. Some of the information relates to ordinary rents and some to landgavel, but the number of properties for which both rent and landgavel are recorded is relatively small. Cole identifies the street in which each property is located, but does not always give its exact location. However he describes in detail the itinerary that he followed when compiling the rental, and by reconstructing this it is possible to determine, not the exact location of a property, but which other properties are adjacent to it.

Data is available on both ordinary rent and on landgavel. Ordinary rent is typically paid annually by an occupier to an owner, but in some cases a lessee (the holder of a long-term lease) may also be involved; if so, the rent recorded is normally the amount paid by the occupier to the lessee, it would seem, rather than the amount paid to the owner by the lessee (indeed, the lease may have been purchased for a lump-sum, so that no annual rent is paid by the lessee). Ordinary rents in Gloucester were examined by Langton (1977, Table II, p. 266), who classified a sample of 86 properties into seven categories. He found that average rents were highest on principal tenements and tenements with business premises, and lowest on land and shops. Unlike the present study, however, he did not control for variations in location when comparing rents.

The origins of landgavel are obscure, but it appears to have been a tax paid to the king or local lord in lieu of labour or military service (Maitland, 1898, p.180). In the time of Edward the Confessor, and at Domesday, it was levied on strips of land, but it was later levied on houses too. In an urban context it may have been paid to cover the cost of maintaining town facilities not financed out of other sources, such as market tolls or murrage; in effect, it became analogous to a local rate. The basis on which it was set remains unclear. In some towns, such as Lincoln (Hill, 1948, p.58), it was a fixed amount, but in Gloucester it varied between properties, suggesting that Gloucester may have a later version of the tax (Heighway, 1988, p.9). In 1455 the number of properties paying landgavel in Gloucester was largely unchanged since about 1100. It has been suggested that the extent of the Anglo-Saxon 
burh is indicated by those tenements which later paid landgavel (Langdon, p.267), but fact that landgavel was levied on the area between the Foreign Bridge and West Gate, which archaeological evidence suggests was not colonised until the $12^{\text {th }}$ century, leads Heighway $(1988$, p.9) to suggest that at least some of the landgavel obligations of 1455 arose no earlier than the 12 th century.

\section{III}

\section{The evolution of the town}

Gloucester lies on the east bank of the River Severn, and was the first crossing point by road for traffic from London to South Wales until the first motorway suspension bridge was built. Long -distance traffic from London entered the town along Northgate and turned right into Westgate at the High Cross. At the High Cross the route crossed the main road down the east bank of the River Severn from Worcester and Tewkesbury to Bristol. The topography of medieval Gloucester was examined in detail by Fullbrook-Leggatt $(1945,1946)$, but the most comprehensive discussion is to be found in Herbert (1988). Excellent sets of maps are provided by Langton (1977), Herbert (1988) and Baker and Holt (2004).

The present city is built over the site of a Roman town, with part of the wall preserved under the Eastgate shopping centre. The street plan is mainly Anglo-Saxon, with a $10^{\text {th }}$ century planned settlement being in-filled and 'suburbanised' in the $11^{\text {th }}$ and $12^{\text {th }}$ centuries by the development of trades and residences outside the city walls (Heighway, 1988, 1995). After the Norman conquest the defences were strengthened by means of new walls, gates and a moat. Two outer gates were built on part of the River Twyver (also known as the Full Brook), which flows through the northern part of the town (Fullbrook-Leggatt, 1964). Between 1104 and 1113 the precincts of St. Peter's Abbey (later the cathedral) were walled and extended, and about the same time a castle was built to the south-west of the town centre overlooking theport on the River Severn (Herbert, 1989, p.63).

The Severn had three channels at this time. One ran to the west of the town, on the far side of Alney Island, a tract of low-lying meadow; the central channel, known as the Great Severn, passed under Westgate Bridge; whilst the Little Severn to the east, nearest the town, passed under Foreign Bridge near St. Nicholas's Church. The middle channel appears to have carried the greater volume of water in the middle ages. The port of Gloucester was close to the point where the Great Severn and Little Severn diverge (Herbert, 1989, p.63). The Little Severn is now a small underground watercourse, but the other channels remain in use.

In Anglo-Saxon times suburbanisation was mainly confined to the area between the Northgate and the outer gates on the Tewkesbury road and London road; the streets included Her Lane, Back Her lane, and Bride Lane (Heighway, 1983). It seems likely that expansion to the west, across Foreign Bridge toward Westgate Bridge, occurred no earlier than the $12^{\text {th }}$ century. According to tradition, St. Bartholomew' Hospital was built in this area during the reign of Henry II; it was later rebuilt on higher foundations because of the risk of flooding (Ellis, 1929). Further expansion occurred on monastic lands outside the city walls during the $12^{\text {th }}$ and early $13^{\text {th }}$ centuries (Herbert, 1989, pp.66-7). 
Trade and industry were well established by the beginning of the $13^{\text {th }}$ century. By this time, according to Herbert (1989, p.26) 'the smiths' forges had given the name of the smiths' street to the later Longsmith street in the south-west quarter of the town, and the sign of the Bolt inn which later gave that street the alternative name of Bolt Lane presumably recalled the manufacture of crossbow bolts. A street leading off the smiths' street had had become known as Broadsmith Street by the early $14^{\text {th }}$ century, and a lane off the main market area, formerly Craft's Lane, acquired the name Ironmongers' Row, at least two dealers in iron being resident there in1333. Some ironworkers also settled in the suburbs of the town: in the mid-13 $3^{\text {th }}$ century two smiths and three farriers were among inhabitants of the Newland and Fete Lane area outside the north gate.' Dyers and fullers had established themselves along the River Severn and the River Twyver by c.1230; additionally, cordwainers were prominent in Northgate Street and tanners in Her Lane.

After the Black Death the population probably remained fairly stable at around 4500-5000, but the luxury trades such as goldsmith, mercer and vintner seem to have gone into decline. This may have been been part of a general decline around this time; there is little evidence that Gloucester was losing trades to competitor towns such as Bristol and Worcester (Holt, 1985).

\section{The town at about the time of the rental}

The four streets meeting at the High Cross were sometimes referred to as the 'great streets' and were the only ones subject to paving powers in 1473 (Dancey, 1901). The key administrative centres were the Boothall, or guildhall (recorded from 1192), in Westgate, the Tolsey at the High Cross, and a Council House at the East Gate. There was a long-established mint located near Holy Trinity church. There were a large number of inns, to cater both for long-distance travellers into Wales and for pilgrims visiting the shrine of King Edward II at St. Peter's Abbey. (Herbert, 1989, p.38)

Westgate was the longest and most important street. By the mid- $12^{\text {th }}$ century the area of Westgate Street near the High Cross had emerged as the main market area. At the time of the rental, one side was known as the Mercery and the other as the Butchery. There were two parish churches in the centre of the street, and two more at the High Cross itself. The Kings Bord (which may have displayed the rules of the market) was also in the middle of the street. Southgate was the Bristol road; it was also a retail centre, and at various times handled fish and wheat.

Eastgate was originally the least favoured of the four main streets, being the Jewish quarter until 1275. It led out to the two bartons from which the royal and abbey estates adjoining the town were administered, and to the small market town of Painswick, but its importance as a route of commerce probably dated only from the beginning of the Middle Ages with the development of the Stroud Valley cloth-making area.

As in many medieval towns, a substantial amount of land was owned by religious institutions; not only by the Benedictine Abbey of St. Peters, but also by St. Oswald's Priory, located near the River Severn, a Dominican Friary (Blackfriars, near Satires Lane), a 
Franciscan Friary (Greyfriars, near Southgate Street and Travel Lane), and a Carmelite Friary (Whitefriars, close to the outer wallto the north of the town). These lands, being owneroccupied, were excluded from the rental, but need to be accounted for because they had a crucial influence on the topography of building in the town (Baker and Holy, 2004).

The main trades were iron manufacture, wool export and wine import; also leather working, corn collection and tax payment. Gloucester was dependent on Bristol for international trade; shipping on the River Severn trade often passed by, coming south from other centres upstream. Much of the carrying by sea and land was in the hands of carriers based outside Gloucester. (Herbert, 1989, pp.46-50).

There is evidence, however, that by the time of the rental the town was in decline. In 1447 the townspeople appealed that the town was 'depopulated by plague and that hardly $£ 40$ of the annual fee farm of $£ 60$ could be collected' (Herbert, 1989, p.36) A request for paving powers in 1455 cited great poverty. In 1483 the fee farm was reduced to £20. Between 1423 and 1481 the number of unfranchised foreigners and inhabitants that paid for trading rights fell from c. 252 to 108, and the number who can definitely be identified as traders from outside the town fell from 98 to 33 (Herbert, 1989, pp.36-7)

IV

In making statistical inferences it is important to assess how far the sample of properties is representative of the town as a whole. Like any investigator, Cole had to determine the geographical scope of his study. He did not confine himself to the boundaries of the old Roman town, nor to the boundaries associated with the outer gates of the medieval city; he included suburbs close to the city as well. He focused on suburban properties to the north and east of the city, to either side of the London road, and neglected suburbs to the south and east, on low-lying ground close to the River Severn, which were possibly inhabited by poorer people who did not necessarily have legal title to their properties.

Within his chosen boundary, Cole appears to have striven for comprehensive coverage, as he includes a wide variety of properties, including many in small lanes such as Satires Lane and St. Cyneburg's Lane. Cole's itinerary was re-traced for the purposes of this study and a concordance between the modern town and the medieval one is available on request from the authors. It seems that Cole had difficulty in obtaining comprehensive evidence on rents; most of this evidence appears at the beginning of the study, which is focused on Southgate Street, the Mercery and the Butchery. Otherwise it includes information only on selected central lanes, such as Travel Lane and Smith Street, and on properties to the north and east around Her Lane. Not surprisingly, is seems that he had better information about rents paid to his employer, the Prior of Llanthony, rather than to other landlords, which means that the Prior's properties are probably over-represented in the study of rents.

The problem of data availability is less serious where landgavel is concerned. There are about three times as many properties for which landgavel is reported, although even here there are some systematic gaps, such as in the area around St. Aldhelm's Lane and Oxbode Lane, to the north east of the High Cross. The larger number of properties in the sample, and the more 
even geographical coverage, mean that the results for landgavel are probably more reliable than the results for rent. Nevertheless, over 100 observations on rent are included in the study.

\section{V}

Qualitative and quantitative data were extracted from the printed edition of the rental (Stevenson, 1890), in which the translation appears on the right hand pages opposite the Latin text. The printed edition was validated by consulting an original held in the Gloucestershire Archives (see above). Only properties for which rent or landgavel payments were recorded were included. To identify the location of each property it was necessary to refer to the itinerary (see Appendix), but for convenience properties were listed in the database in the order in which they appear when reading the book in the normal way. Each property was identified uniquely by the row of the database (numbered 1-457) and by its page reference [page number, column; sequence in the column] (the page reference is not unique when the entry relates to multiple properties).

The columns of the Excel database contain the names of the street, the owner, the lessee and the occupier, and the key characteristics of the property (e.g. type of land or building, use of the property, and the trades or professions that may have been practised there). Rent and landgavel are recorded separately in pence.

Qualitative information was converted into quantitative information using binary dummy variables. In regression analysis one of the dummy variables always needs to be used as a control. The estimated coefficients associated with the remaining dummy variables then measure the discrepancy between the impact of that variable and the impact of the control, as explained below. It was necessary to ensure that each binary variable corresponds to meaningful variation in the sample. Because there are more observations on landgavel, a wider range of dummy variables could be employed to analyse landgavel payments (see below).For the purposes of rent analysis, streets were classified in four ways, namely Southgate, Mercery and Butchery, Central side lanes, and the North east (mainly outside the inner wall), as indicated in Table 2 below. For landgavel analysis twelve areas were identified, as shown in Table 3. Southgate has by far the largest number of observations, and is therefore used as the control location in both cases.

Owners are resolved into seven categories. The most numerous category, private male owner, is used as the control for the landgavel analysis. The Prior of Llanthony and the Abbot of St. Peter's are identified individually because their institutions both owned a large number of properties. 'Local religious institutions' is a category that includes many corporate bodies associated with Gloucester churches; 'External religious institutions' includes the abbots of Winchcombe and Hailes; 'Civic institutions' includes the Stewards of Gloucester and the Community of Gloucester; finally there are several private woman owners, some owning several properties. However, there were too few relevant observations to include women and external religious organisations in the analysis of rent; only four categories of owner are distinguished - the prior, the abbot, local religious institutions and local civic institutions - 
with a control group comprising private owners (both male and female) and external religious institutions.

Fifteen characteristics of a property are identified; they are selected so that a reasonable number of properties appear in each category in the landgavel analysis: ordinary tenement (the most common group, and also the control group), principal tenement, or tenement with additional buildings (e.g. a bake-house), a toft (which appears to refer to a building with attached garden or vacant land), an inn, a shop (including sheds and booths used for retailing), a cottage, a stable (sometimes converted from a cottage), a corner property (mainly at the junction of a principal street and a side street), a new building, an empty building or vacant lot, a multiplicity of dwellings (e.g. through subdivision of large tenement), a 'parcel' (part of a tenement or plot of land), a building where the occupier is noted as practising a trade, or where the surname suggests a particular trade, a building where the occupier is associated with a profession, such as cleric or lawyer, and a building where one of the occupiers (usually the only one) is a woman. Because of data limitations, only eight categories appear in the rent analysis: principal tenements, inns, shops, cottages, corner properties, new buildings, empty buildings, and plots where the occupier practises a trade are each compared with a control group of all other properties.

\section{VI}

The hypotheses to be tested are derived from principally from mainstream literature in urban economics (Boyle and Kiel, 2009; Dunse and Jones, 1983), but also from secondary literature on the history of medieval towns (see above). Thus the hypothesis that centrally located properties pay higher rents than others comes directly from economic theories of urban rent, whilst the hypothesis that properties fronting onto main streets pay higher rents than those fronting onto side lanes and back streets comes from the historical literature.

All the hypotheses are presented in a positive voice; null hypotheses are supported when the maintained hypothesis is rejected. For example, the hypothesis that landgavel is arbitrary is a null hypothesis, and is investigated by testing the positive hypothesis that landgavel payments are systematically related to location, ownership and type of property, and determining whether this positive hypothesis can be rejected. Likewise the null hypothesis that market rents are determined by impersonal market forces, so that ownership of a property has no influence on the rent that is paid, is tested by postulating that ownership affects rent, and examining whether the positive hypothesis can be refuted.

Some hypotheses represent a 'common sense' approach to rent, e.g. that empty properties and ruined properties have lower rents, and that corner properties have higher rents.

\section{General factors influencing rent and landgavel}

I.1. The location of a property influences both the amount of rent and the amount of landgavel paid (when controlling for the impact of ownership and type of property). This hypothesis implies, amongst other things, that landgavel payments are influenced by location in the same way as ordinary rents. 
I.2. The type of property influences both rent and landgavel, when controlling for other factors. This hypothesis articulates the view that every property is different to some extent, and that differences will affect the value of the property. This view is supported by common sense and by economic theory. It must be recognised, however, that some characteristics of a property may be much more important than others where rents are concerned.

I.3. The ownership of a property influences both rent and landgavel, when controlling for other factors. If all owners sought to maximise rents and rents were competitively determined then ownership would not normally matter. In practice, however, some owners may adopt an ethical approach, and take account of the existing occupant's ability to pay. Rents may also be subject to political influence; it is possible, for example, that powerful religious institutions may have used their influence to reduce assessments for landgavel on properties that they owned (see below).

\section{Specific factors influencing both rent and landgavel}

II.1. Location is the most important factor in explaining the variation of rent and landgavel payments across properties.

II.2. Central location, and location on main streets rather than side streets, attract higher rent and landgavel.

II.3. The practice of a trade or profession attracts a higher level of rent or landgavel.

II.4. Shops, principal tenements, corner properties and new properties all attract higher rents than ordinary tenements, and possibly higher landgavel. Empty properties attract lower rents.

\section{Differences between rent and landgavel}

III.1 Religious institutions pay less landgavel than private owners, when controlling for the location and type of property (see above).

III.2. Rent is more sensitive than landgavel to location and type of property. This reflects the view that market forces impact more heavily on rents than on landgavel.

\section{Additional factor: spatial autocorrelation}

IV. Adjacent properties tend to have similar rents and similar landgavel payments, after controlling for differences in ownership and type of property. This hypothesis is derived from urban economic theory, which suggests that the value of a property will be influenced by the characteristics of neighbouring properties, and that this will be reflected in its rent. Neighbouring properties may also have similar rents because they benefit from proximity to some local facility (e.g. a well) or suffer from proximity to some nuisance (e.g. a tannery).

\section{VII}

The hypotheses specify three groups of factors- location, ownership and type of propertythat influence rent and landgavel. It is possible that these factors could interact in subtle 
ways, but the simplest approach is to assume that they interact additively or multiplicatively. Consider, for example, the size of the building and its location. If interaction were additive then large size would increase rent by the same amount whatever the location, and location would increase rent by the same amount whatever the size. On the other hand, if interaction were multiplicative, then large size would increase rent by an amount proportional to the value conferred by the location, whilst location would increase rent by an amount proportional to size. Multiplicative interaction is clearly more plausible than additive interaction. Multiplicative interaction is easy to model because it implies that factors impact additively on the logarithm of rent rather than on the absolute level of rent (as in the additive case).

Most of the hypotheses presented above can be tested using a multiple linear regression of rent on the three groups of factors identified above. The explanatory variables are all dummy variables. With three location dummies, seven property dummies and four ownership dummiesthere are fourteen explanatory variables (plus a constant term to represent the control groups) in the full rent regression. With 103 usable observations there are 103-15=88 degrees of freedom, which is perfectly adequate for statistical analysis. Where landgavel is concerned, there are eleven location dummies, sixteen property dummies and six ownership dummies (plus a constant term) and with 378 usable observations there are 378-34 $=344$ degrees of freedom, which is more than adequate for statistical purposes.

The goodness of fit of the regression is measured by $R^{2}$, and the overall significance by an $F$ statistic. Hypotheses are tested by reference to the sign and significance of relevant dummy variables.

Preliminary statistical analysis shows clearly that the logarithm of rent is far easier to explain than variation in the absolute level (as measured by $R^{2}$ ). The multiplicative account of interaction is clearly vindicated, and so only logarithmic results are reported below.

To minimise the risk of specification error, a range of diagnostic tests were applied. The significance levels are calculated using White's adjustment for heteroskedasticity. Residuals were carefully examined for outliers (where the actual observation is more than two standard deviations from the predicted value). Jarque-Bera tests reveal that the residuals from the rent regressions are not generally normally distributed, but that the residuals from the landgavel regressions are reasonably close to normality. The normality of the rent residuals would be improved by eliminating outliers, but nevertheless outliers were retained to avoid 'datamining'. In several rent regressions there is a single prominent outlier, which corresponds to the only 'ruinous' property in the rental sample. There are no problematic outliers in the landgavel sample because the larger number of observations means that a wider range of explanatory variables (including a dummy variable for ruined or decayed properties) could be used in the regression.

There is a possibility of endogeneity in some explanatory variables, notably the 'empty property' dummy, but data limitations make it difficult to formally address this issue (e.g. there are no suitable instrumental variables). 


\section{VIII}

The results of the rent regressions are presented in Table 2. The explanatory variables are listed on the left-hand side. In each cell the impact coefficient for the relevant dummy variable is reported, with its significance level shown in brackets below. Summary statistics are reported in the last four rows. Column 1 analyses location factors only, column 2 property characteristics only and column 3 ownership only. Location and property characteristics are combined in column 4, location and ownership are combined in columns 5, property characteristics and ownership are combined in column 6 and all the factors are entered into column 7. This step-wise approach is used purely for expository purposes. It shows how the impacts imputed to one set of factors changes when another set of factors is introduced into the regression. Correlations between the explanatory variables mean that some changes are to be expected, but if there were major changes, such as frequent significant sign reversals, it could suggest that the number of observations involving certain characteristics is too low to generate robust results.Because the dummy variables have been chosen with these concerns in mind, no major problems appear in the table.

The final column containing all the variables is the key to interpretation. It shows that, compared to Southgate, the Mercery and Butchery area has significantly higher rents, whilst the central side lanes have significantly lower rents. In the north east area of the town the rents are not significantly different from those in Southgate. These results are based on likefor-like comparisons of properties. Since Mercery and Butchery areat the heart of the central shopping area, the results are consistent with the view that rents are higher in the centre. However, the north-east, which is somewhat more peripheral, does not have lower rents than Southgate, which suggests that centrality may work more strongly over short distances within the city walls than it does over longer distances either side ofthe walls; the number of observations for the north-east area is relatively small, however, so too much weight should not be placed on this particular result. The proposition that frontages on major streets generate higher rents is fully supportedby the negative coefficient for the central side lanes; Mercery, Butchery and Southgate are all major streets, whereas the central side lanes are most definitely not.

The results for types of property are mixed. The control group comprises ordinary tenements. As expected, large properties that include adjoining buildings (e.g. bake houses and workshops) pay higher rents, while cottages pay significantly lower rents. Neither new properties nor corner properties attract higher rents, however. It seems unlikely that the quality of new building was lower, given the surviving evidence from the period, but it is possible that rents were declining and that new buildings therefore had to be rented for less than existing tenancies.

Most of the corner properties lay at the corner of a main street and a side street, or at the corner of two side streets, and may have incurred some nuisances as a result; unlike prestigious properties at the corner of two major streets therefore, they may not have attracted a premium.For empty properties the rent recorded is the rent paid by the last tenant, and so there is no particular reason why it should be low. In fact it is higher than average, although 
not significantly so. One possibility is that the property is empty because the rent is high; this may be why the previous tenant quit, and why the property cannot be re-let until the rent is reduced. This is consistent with the scenario of declining rents set out above.

Shops do not carry a rent premium. This may reflect the fact that some of the shops were probably little more than sheds or booths attached to the sides of other buildings, such as citycentre churches. It could also reflect the fact that the conversion of central properties to shop use was at an equilibrium, in which no further premium was available for creating yet another shop. On average the rent of a shop is slightly below the rent of a standard tenement (though not significantly so); this suggests that if anything there were too many shops, and that economic advantage lay in converting marginal shops to residential use; this is also consistent with a scenario of urban decline.

Inns appear to be the main factor in high rents. Indeed, it is known that new inns were being built at this time, or shortly afterwards (Household, 1946; English Heritage, 2013). This could have been the result of a growth in long-distance trade through Gloucester, or possibly an increase in the pilgrimage trade associated with St. Peter's Abbey. If so, it may indicate a re-orientation of the town's economy away from local trade and towards long-distance trade.

The practice of a trade also increases rents. The practice of a trade is mainly inferred from the description of the premises, the occupation of the tenant, and in some cases simply from the tenant's name. There is clearly a strong effect of some kind, and the most plausible explanation is that tradesmen required specific types of premises that were in limited supply. It is possible that controls on 'nuisance' trades restricted the supply of suitable premises and provided a premium for their owners. Unfortunately there are too few premises in the study to allow a more detailed statistical examination of this issue.

The only significant result for ownership is that the Prior of Llanthony tends to receive lower rents for his property than others, on a like-for-like basis. This could reflect the charity of the priory, but it could also reflect an inefficient estate management policy. It is possible that this situation may have provided the impetus for Cole's survey. The control for this category comprises mainly private owners. Neither the Abbot of St.Peter's, nor the local religious organisations associated with churches, guilds, chantries and hospitals, differ significantly from private owners. Civic bodies, such as the Stewards of Gloucester, received on average lower rent than private owners, but not significantly so. This result is inconsistent with the picture of rapacious priors painted by some medieval historians; but whether the Prior was an ethical landlord, or merely an incompetent one, cannot be determined on this evidence alone.

The regression explains about two-thirds of all the variation of rents across properties in Gloucester, and its $F$ statistic is highly significant overall. The conclusion must be that rents in Gloucester were clearly influenced by systematic economic factors. Examination of these factors has suggested a number of potential insights into the economy of the town as a whole.

IX 
It might be expected that the situation regarding landgavel would be very different. The results are reported in Table 3. The format is exactly the same as in Table 2. The results are certainly different in some respects, but there are striking similarities too. The proportion of variation in landgavel explained by the regression is only 27 per cent, which is less than half that of the rent regression. On the other hand, the overall significance of the regression, as indicated by the $F$ statistic, is high. The simplistic view that landgavel is arbitrary can therefore be rejected at the outset.

When interpreting the results for landgavel, it needs to be remembered that it is not paid by the occupier to the owner or lessee, but by the owner to a third party (the king, local lord or local community, as appropriate).

Once again, detailed interpretation focuses on the final column of the table. The results in the first six columns merely underline the robustness of the results; introducing new sets of variables alters coefficients in the expected manner, but dramatic sign reversals do not occur.

Landgavel clearly conforms to the centrality principle. Taking Southgate as a central area, the other central areas of Mercery and Butchery, Westgate, Northgate and Eastgate all have positive though insignificant coefficients, suggesting that they are basically similar to Southgate, but slightly more prosperous. By contrast, peripheral areas such as Outside Eastgate, Between the Bridges (to the west), and Her Lane (to the north-east) are associated with significant negative coefficients that are indicative of lower rents. Side lanes do not carry the same penalty as before: neither central side lanes nor Bareland have landgavel significantly different from Southgate. Ironically, therefore, landgavel demonstrates centrality even more strikingly than rent, even though the latter is usually assumed to be more affected by market forces.

Further evidence of market forces is provided by the results for propertycharacteristics. Once again, inns carry a highly significant positive coefficient, as does the practice of a trade. This shows that the impact of commercial activity on value is common to both rent and landgavel. Once again, shops, corner plots and new buildings do not significantly differ in value from the control group of ordinary tenements. On the whole, therefore, the pattern of variation in landgavel payments is remarkably similar to the pattern for rent. Indeed, the overall pattern of variation is highly convincing; although large tenements do not carry a premium, tenements with multiple occupants living separately certainly do.

With respect to ownership, landgavel payments reveal no significant effects. In this respect their pattern is more aligned with the outcome of a pure market process than in the case of rent, where the Prior of Llanthony appeared to be pursuing an idiosyncratic policy. The Prior certainly pays on average less landgavel, on a like-for-like basis, than other owners, which could be taken as a sign of royal favouritism, but the discrepancy is not significant. However landgavel was set, it certainly seems to have been set under the influence of economic factors.

The greater number of observations relating to landgavel makes it possible to test hypotheses regarding the role of woman as owners and occupiers of property. If women were a 
vulnerable group then it would be expected that women owners and occupiers would pay high landgavel. There is no evidence that women occupiers are vulnerable; so far as woman owners are concerned, they pay, on average, higher landgavel than men, on a like-for-like basis, but not significantly so. Overall, therefore, the results suggest that gender has little or no influence on landgavel.

\section{$\mathbf{X}$}

So far rent and landgavel have been analysed separately, on the basis that they need to be treated differently because one is more market-driven than the other. The remarkable similarity between rent and landgavel suggests, however, that there could be a relationship between them. This relationship could be no more than a common dependency on market forces, which is stronger in the case of rents but non-negligible in the case of landgavel. Another possibility, however, is that rents are actually set, at least partly, on the basis of landgavel payments, by scaling up landgavel to a prevailing market-driven level.

A simple way to test this view is to include landgavel as an additional explanatory variable in a rent regression. If rent and landgavel simply exhibit common dependence on the same explanatory variables then landgavel will not appear significant when introduced into a rent regression. If, on the other hand, landgavel is used as a benchmark in setting commercial rents, because it is believed to embody historical factors that remain relevant, then it will appear significant in its own right. The practical difficultly is that there are only 34 properties for which both rent and landgavel data are available. This restricts the number of explanatory variables that can be used in the regression equation. Several of the dummy variables included in Table 2 need to be dropped because of insufficient observations. The result is the regression displayed in Table 4 shows that, subject to these limitations, landgavel does not directly affect rent. The coefficient on landgavel, which appears in the second row of the table, is negative and insignificant, indicating that landgavel does not influence ordinary rent. This validates the approach adopted above, in which rent and landgavel are regarded as independently determined by the same set of factors.

\section{XI}

Spatial correlation implies a positive association between rents paid by adjacent properties. It is a well-known feature of contemporary property markets, and so it is interesting to inquire whether it is characteristic of medieval Gloucester too. The existence of spatial correlation does not affect the reliability of the estimated regression coefficients reported above, although it does mean that the significance tests need to be treated with care. Spatial autocorrelation applies to properties on a like-for like basis. This means that correlation is predicted to occur in the residuals of the estimated regressions rather than in the rents themselves.

To investigate spatial autocorrelation it is necessary to identify all pairs of properties which are adjacent to each other and for which either rent or landgavel information is available for both. This requires a careful reading of the rental, as presented in the Appendix. It is possible to identify 23 pairs of neighbouring properties for which rent information is available and 193 
pairs for landgavel. The results are presented in Table 5, which shows that there is significant spatial autocorrelation in both rent and landgavel. The correlation is lower for landgavel than for rent, but is statistically more significant because of the greater number of observations involved. This result underlines the basic similarity between rent and landgavel; namely the presence of market-like patterns in the data for both, and the way that effects observed in rent data are almost invariably reproduced in weaker form in the landgavel data.

\section{XII}

The principal findings from the statistical analysis may be summarised as follows:

- Rents and landgavel are both influenced by the location and type of property.

- There is no evidence that landgavel is less sensitive than property to location and use. This result must be qualified, however, because the two samples of properties are not directly comparable. The sample for landgavel is both larger and more geographically diverse than the rent sample, so that positive coefficients on location and use are more likely to appear significant.

- Central locations attract higher rents and also higher landgavel. For rents 'centrality' applies mainly to the area around the High Cross, while for landgavel the distinction is more between the areas inside and outside the city walls, or to the areas east or west of Foreign Bridge over the Little Severn.

- Locations on main streets attract higher rents than on side streets, but not higher landgavel. It is possible that the difference may arise because main street location is of greatest social significance in the centre of the town, from which most of the rental information was collected.

- Inns carry high premia for both rent and landgavel. Trade and professional use also carries premium in both cases.

- Shops, corner properties and new builds do not command premia. Most shops are in the centre, where rents are already high, but they may be merely sheds or booths which are less substantial than conventional residential buildings. Corner properties may not carry a premium because their location is associated with greater noise and nuisance, and therefore does not carry higher status. New builds may not command a premium because at the time of the survey the property market was depressed, and so, while rents on existing properties had not been reduced (possibly due to the term of the rental agreement), rents for new properties had to be set at lower levels.

- On the other hand, major tenements commanded a premium for rent and multiple residency commanded a premium for landgavel, as expected. Cottages incurred a discount for rent, which may reflect the reduced floor space. The depressed state of the market may be reflected in the facts that several cottages were in use as stables.

- Ownership has some modest influence on rents - certainly more than would be expected if landowners were well informed and the land market was perfectly competitive. It is not, however, simply a question of religious institutions receiving more rent or paying less landgavel. Some of the regression results suggest that local religious institutions and civic institutions pay less landgavel than private male 
owners, but this becomes insignificant once the use of properties is controlled for. So far as rent is concerned, the Prior of Llanthony receives lower rents than private owners when properties are compared on a like-for-like basis. The relatively poor return obtained by the Prior may explain, in part, why it was one of his canons that carried out the survey on behalf of the priory and the wider community of Gloucester.

It appears that, in the case of Gloucester at least, market forces had a significant impact on rents and landgavel payments. While landgavel payments may indeed have ossified to some extent, it is possible that, contrary to previous views, the ossified levels simply reflected similar economic forces operating at an earlier date. The most straightforward explanation of the results for rents is that competitive market forces were operating in the urban land market at the time of the survey. While these forces may have been moderated by social custom and political obligation, the proportion of the variation in rents explained by economic factors is sufficiently high that the role of market forces cannot reasonably be ignored. These results are consistent with Langton's (1977, p.266) assessment that '... rents seem to display variations, according to the type of location of properties, consistent enough to suggest that by and large profits were sought from holdings along essentially economically rational lines and that a marker kept rents and values in reasonable unison.'

The advantage of hedonic regression, as used in this paper, is that it provides a systematic approach to the analysis of rents that can be applied to all towns for which suitable rentals are available, and that it makes it possible to generate a comparative analysis of urban rents across towns (and potentially over time as well). In order to develop this comparative approach it would be beneficial to extend the analysis to the other towns outlined in Table 1. 


\section{Bibliography}

Allen, Robert C. (1988), The price of freehold land and the interest rate in the seventeenth and eighteenth centuries, Economic History Review, 41, 33-50.

Baker, Nigel and Richard Holt (2004) Urban Growth and the Medieval Church: Gloucester and Worcester, Aldershot: Ashgate

Biddle Martin (ed.) (1976) Winchester in the Early Middle Ages, Winchester Studies 1, Oxford: Clarendon Press

Boyle, Melissa A. and Katherine A. Kiel (2009) A survey of house price hedonic studies of the impact of environmental externalities, Journal of Real Estate Literature, 9 (2), 117-144

Bouchard, ConstanceBrittain (1991) Holy Entrepreneurs: Cistercians, Knights, and Economic Exchange in Twelfth-century Burgundy, Ithaca, NY: Cornell University Press

Burgess, L.A. (1976) The Southampton Terrier of 1454, London: HMSO for Historical Manuscripts Commission, JP21, and Southampton: Southampton Records Society, New series, Vol. XV

Butcher, A.F. (1978) Rent, population and economic change in Late-medieval Newcastle, Northern History, 14, 67-77

Butcher, A.F. (1979) Rent and the urban economy: Oxford and Canterbury in the Later Middle Ages, Southern History, 1, 11-43

Chitty, Herbert (n.d.) Winchester Tarrage Roll of 1418, with introductory notes by J.H. Harvey, Winchester College Muniments WCM1005

Clark, G. (2002), Land rental values and the agrarian economy: England and Wales 15001914, European Review of Economic History, 6(3), 281-308.

Dancy, C.H. (1901) The High Cross at Gloucester, Transactions of the Bristol and Gloucestershire Archaeological Society, 24, 293-307

Davis, R.W.C. (925) London lands and liberties of St. Paul's, 1066-1135, in A.G. Little and F.M. Powicke (eds.), Essays in Medieval History in honour of W.F.Tout, Manchester : Manchester University Press, 45-59

Dobson, R.B. (1977) Urban decline in late medieval England, Transactions of the Royal Historical Society, $5^{\text {th }}$ series, 27, 1-22

Dunse, Neil and Colin Jones (1983) A hedonic price model of office rents, Journal of Property Valuation and Investment, 16 (3), 297-312

Ellis, M.H. (1929) The bridges of Gloucester and the hospital between the bridges, Transactions of the Bristol and Gloucestershire Archaeological Society, 51, 169-210 
English Heritage (2013) New Inn, Gloucester, http://list.english-

heritage.org.uk/resultsingle.aspx?uid=1245714 (accessed 14/11/2013)

Fullbrook-Leggatt. L.E.W.O. (1945) Medieval Gloucester: I, Transactions of the Bristol and Gloucestershire Archaeological Society, 66, 1-48

Fullbrook-Leggatt. L.E.W.O. (1964) Medieval Gloucester: II, Transactions of the Bristol and Gloucestershire Archaeological Society, 67, 217-306

Fullbrook-Leggatt. L.E.W.O. (1964) The River Twyver and the Fullbrook, Transactions of the Bristol and Gloucestershire Archaeological Society, 83, 78-84

Goddard, Richard (2004) Lordship and Medieval Urbanisation: Coventry, 1043-1355, Woodbridge: Boydell

Greenwell, William (ed.) (1852) Boldon Buke: A Survey of the Possessions of the See of Durham, Durham: Surtees Society, Vol. 25

Greenwell, William (ed.) (1857) Bishop Hatfield's Survey, Durham: Surtees Society, Vol. 32

Harding, Vanessa and Laura Wright (eds.) (1995) London: Selected Accounts and Rentals, 1381-1538, London: London Record Society

Hatcher, John (1996) The great slump of the mid-fifteenth century, in Richard Britnell and John Hatcher (eds.) Progress and Problems in Medieval England: Essays in Honour of Edward Miller, Cambridge: Cambridge University Press

Heighway, Caroline (1983) Tanners' Hall, Gloucester, Transactions of the Bristol and Gloucestershire Archaeological Society, 101, 83-109

Heighway, Carolyn (1988) Anglo-Saxon Gloucester, c.680-1066, in N.M. Herbert (ed.) The Victoria History of the County of Gloucester, Vol. IV: The City of Gloucester, London: Oxford University Press for the Institute of Historical Research, 5-12

Heighway, Caroline (1995) Gloucester: A History and Guide, Stroud: Alan Sutton

Herbert, Nicholas M. (1988) Medieval Gloucester, 1066-1547, in N.M. Herbert (ed.) The Victoria History of the County of Gloucester, Vol. IV: The City of Gloucester, London: Oxford University Press for the Institute of Historical Research, 13-72

Hill, J.W. Francis (1948) Medieval Lincoln, Cambridge: Cambridge University Press Horrox, Rosemary (ed.) (1983) Selected Rentals and Accounts of Medieval Hull, York: Yorkshire Archaeological Society, Records series, Vol.116

Holt, Richard (1985) Gloucester in the century after the Black Death, Transactions of the Bristol and Gloucestershire Archaeological Society, 103, 149-161

Household, H.G.W. (1946) The Fleece in Upper Westgate Street, a 'Great Inn' of about 1500, Transactions of the Bristol and Gloucestershire Record Society, 67, 37-57 
Keene, Derek (1985) Survey of Medieval Winchester, Winchester Studies Vol. 2 i, Oxford: Clarendon Press (see especially pp. 27-29)

Keene, Derek (1989) The property market in English towns AD 1100-1600, in J.-C. Maire Vigeur (ed.) D'Une Ville a l'autre: Structures, Materielles et Organisatiin de L'Espace dans les Villes Europeens, VIII ${ }^{e}-X V I^{e}$ Siecle, Rome, 201-226

Keene, Derek and Vanessa Harding (1985) A Survey of Sources for Property Holding in London before the Great Fire, London: London Record Society, Vol. 22

Kerling, Nellie J.M. (ed.) (1973) Cartulary of St. Bartholomew's Hospital, London: St. Bartholomew's Hospital

Langston, J.N. (1942) Priors of Llanthony by Gloucester, Transactions of the Bristol and Gloucestershire Archaeological Society, 63, 1-144

Langton, John (1977) Late medieval Gloucester: Some data from a Rental of 1455, Transactions of the Institute of British Geographers, New series, 2, 259-277

Lee, John S.(2005) Cambridge and it Economic Region, Hatfield: University of Hertfordshire Press

Lomas, R.A. and A.J. Piper (eds.) (1989) Durham Cathedral Priory Rentals, Vol. I: Bursars Rentals, Newcastle: Surtees Society, Vol. 189

Maitland, Frederic W. (1898) Township and Borough, Cambridge: Cambridge University Press

Palmer, W.M. (ed.) (1931) Cambridge Borough Documents, Vol. I, Cambridge: Bowes and Bowes

Record Commission (1812-8) Rotuli Hundredorum: Temp. Hen. iii and Edw. i, London: House of Commons

Rees Jones, Sarah Ruth (1987), 'Property, Tenure and Rents: Some Aspects of the Topography and Economy of Medieval York', unpublished PhD thesis, University of York, 2 vols

Stevenson, W.H. (ed.) (1890) Rental of the Houses in Gloucester AD 1455: From a Roll in the possession of the Corporation of Gloucester, Gloucester: J.E. Bellows

Turner, Michael E., John V. Beckett and Bethanie Afton (1997) Agricultural Rent in England, 1690-1914, Cambridge: Cambridge University Press.

Van Bavel, Bas (2008) The organisation and rise of land and lease markets in north-western Europe and Italy, c.1000-1800, Continuity and Change, 23 (1), 1-53

Webb, E.A. (1921) (ed.) Records of St. Bartholomew's Priory, Smithfield, Oxford: Clarendon Press 
Table1: Select list of published transcripts and/or translations of medieval English urban rentals

\begin{tabular}{|c|c|c|c|c|}
\hline Location & Date & $\begin{array}{l}\text { Number } \\
\text { of } \\
\text { complete } \\
\text { entries }\end{array}$ & Document & Most convenient source \\
\hline Cambridge & $\begin{array}{l}1483- \\
1524\end{array}$ & 238 & $\begin{array}{l}\text { High Gable rent in the } \\
\text { borough of } \\
\text { Cambridge, } 1483 \text {, } \\
1491,1493,1524\end{array}$ & Palmer (1931), pp.57-69 \\
\hline Cambridge & $1500-1$ & 76 & $\begin{array}{l}\text { Account of John } \\
\text { Stokill and Thomas } \\
\text { Hunter }\end{array}$ & Palmer (1931), pp.39-43 \\
\hline Cambridge & $1561-2$ & 147 & $\begin{array}{l}\text { Treasurers' Account: } \\
\text { rental portion }\end{array}$ & Palmer (1931), pp.83-91 \\
\hline \multirow[t]{4}{*}{ Canterbury } & $1153-67$ & 37 & $\begin{array}{l}\text { A: Roll of Wibert, } \\
\text { containing the list of } \\
\text { property acquired by } \\
\text { him for the Cathedral }\end{array}$ & Urry (1967), pp. 221-225 \\
\hline & $1163-7$ & 223 & $\begin{array}{l}\text { B: Survey of } \\
\text { Cathedral holdings in } \\
\text { the wards of } \\
\text { Northgate, Burgate } \\
\text { and Newingate }\end{array}$ & Urry (1967), pp. 226-243 \\
\hline & c. 1200 & 388 & $\begin{array}{l}\text { D: A survey with } \\
\text { measurements of } \\
\text { Cathedral holdings }\end{array}$ & Urry (1967), pp. 249-315 \\
\hline & c. 1206 & 669 & $\begin{array}{l}\text { F: A schedule of } \\
\text { Cathedral tenants in } \\
\text { Canterbury, together } \\
\text { with their rents, and } \\
\text { descriptive notes of } \\
\text { their holdings }\end{array}$ & Urry (1967), pp. 315-374 \\
\hline \multirow[t]{4}{*}{$\begin{array}{l}\text { Kingston- } \\
\text { upon-Hull }\end{array}$} & 1320 & 125 & Inquisition & Horrocks (1983), pp.31-51 \\
\hline & 1347 & 215 & Fee farm rental & Horrocks (1983), pp.61-90 \\
\hline & 1465 & 150 & $\begin{array}{l}\text { Rental of the town's } \\
\text { land }\end{array}$ & $\begin{array}{l}\text { Horrocks (1983), pp.111- } \\
120\end{array}$ \\
\hline & $1527-8$ & 192 & $\begin{array}{l}\text { Rental of the town's } \\
\text { land }\end{array}$ & $\begin{array}{l}\text { Horrocks (1983), pp.121- } \\
134\end{array}$ \\
\hline $\begin{array}{l}\text { London, St. } \\
\text { Pauls' }\end{array}$ & $\begin{array}{l}\text { c. } 1128 \\
(1123- \\
1132)\end{array}$ & 25 & $\begin{array}{l}\text { De MensurisTerrarum } \\
\text { Sancti Pauli intra } \\
\text { ciuitatem Lund (Liber } \\
\text { L., Fo. 47-50b) }\end{array}$ & Davies(1925), Appendix \\
\hline London, St. & 1456 & 280 & Rental of all the rents & Kerling (1973), Appendix I \\
\hline
\end{tabular}




\begin{tabular}{|c|c|c|c|c|}
\hline $\begin{array}{l}\text { Barthol- } \\
\text { omew's } \\
\text { Hospital }\end{array}$ & & & $\begin{array}{l}\text { within and without the } \\
\text { City of London from } \\
\text { the time of King } \\
\text { Henry I, by John Cok }\end{array}$ & \\
\hline $\begin{array}{l}\text { London, St. } \\
\text { Barthol- } \\
\text { omew's } \\
\text { Priory }\end{array}$ & 1291 & c. 220 & $\begin{array}{l}\text { Bodleian Rental, } \\
\text { London section }\end{array}$ & Webb (1921), pp. 465-477 \\
\hline $\begin{array}{l}\text { London } \\
\text { Bridge } \\
\text { Trustees }\end{array}$ & 1404 & 88 & $\begin{array}{l}\text { Rental of occupied } \\
\text { and vacant tenements } \\
\text { in diverse parishes in } \\
\text { London and } \\
\text { Southwark }\end{array}$ & $\begin{array}{l}\text { Harding and Wright, } \\
\text { (1995), pp. 30-52 }\end{array}$ \\
\hline Lynn & 1391 & 193 & $\begin{array}{l}\text { Rental of community } \\
\text { property }\end{array}$ & $\begin{array}{l}\text { http://users.trytel.com/ trist } \\
\text { an/towns/lynn4, accessed } \\
01 / 09 / 2013\end{array}$ \\
\hline Southampton & 1454 & 515 & $\begin{array}{l}\text { For the repairs and } \\
\text { stopping up loops in } \\
\text { the town walls } \\
\text { (valuation expressed } \\
\text { in the number of loops } \\
\text { to be maintained) }\end{array}$ & Burgess (1976) \\
\hline Winchester & c. 1110 & 295 & $\begin{array}{l}\text { A record of the lands } \\
\text { which pay landgable } \\
\text { or brewgable in } \\
\text { Winchester }\end{array}$ & Biddle (1976), pp. 32-68 \\
\hline Winchester & 1148 & 1086 & $\begin{array}{l}\text { An inquest concerning } \\
\text { the lands of } \\
\text { Winchester }\end{array}$ & Biddle (1976), pp. 69-141 \\
\hline Winchester & 1418 & $>700$ & $\begin{array}{l}\text { Winchester Tarrage } \\
\text { Roll }\end{array}$ & Chitty (n.d.) \\
\hline
\end{tabular}

Note: Towns are listed in alphabetical order, with rentals for the same town listed in chronological order. Information about specific towns can sometimes be found in rentals that include rural as well as urban properties, e.g, Bolton Buke (Greenwell, 1852), Bishop Hatfield's Register (Greenwell, 1857), and Durham Cathedral Priory Accounts(Lomas and Piper, 1989). The Hundred Rolls contain some rental information for Cambridge, Oxford and Huntingdon, but information on other towns, including London, is either weak or nonexistent (Record Commission, 1812-8). 
Table 2

Regression analysis of impact of location, ownership and type of property on rent

\begin{tabular}{|c|c|c|c|c|c|c|c|}
\hline Explanatory factor & $\mathbf{1}$ & 2 & 3 & 4 & 5 & 6 & 7 \\
\hline Constant & $\begin{array}{c}4.589 \\
(0.000)\end{array}$ & $\begin{array}{c}4.462 \\
(0.000)\end{array}$ & $\begin{array}{l}4.687 \\
(0.000)\end{array}$ & $\begin{array}{l}4.493 \\
(0.000)\end{array}$ & $\begin{array}{l}4.887 \\
(0.000)\end{array}$ & $\begin{array}{l}4.608 \\
(0.000)\end{array}$ & $\begin{array}{l}4.606 \\
(0.000)\end{array}$ \\
\hline \multicolumn{8}{|l|}{ Location } \\
\hline Mercery \& Butchery & $\begin{array}{c}0.589 \\
(0.024)\end{array}$ & & & $\begin{array}{c}0.640 \\
(0.027)\end{array}$ & $\begin{array}{c}0.437 \\
(0.084)\end{array}$ & & $\begin{array}{c}0.546 \\
(0.019)\end{array}$ \\
\hline Central side lanes & \begin{tabular}{|l|}
-1.324 \\
$(0.000)$
\end{tabular} & & & $\begin{array}{l}-0.988 \\
(0.000)\end{array}$ & $\begin{array}{l}-1.328 \\
(0.000)\end{array}$ & & $\begin{array}{l}-0.707 \\
(0.001)\end{array}$ \\
\hline North-east & $\begin{array}{l}-0.076 \\
(0.624)\end{array}$ & & & $\begin{array}{l}-0.042 \\
(0.843)\end{array}$ & $\begin{array}{l}-0.091 \\
(0.745)\end{array}$ & & $\begin{array}{c}0.098 \\
(0.805)\end{array}$ \\
\hline \multicolumn{8}{|l|}{ Type of property } \\
\hline Large tenement & & $\begin{array}{c}0.996 \\
(0.008)\end{array}$ & & $\begin{array}{c}0.786 \\
(0.058)\end{array}$ & & $\begin{array}{c}1.192 \\
(0.001)\end{array}$ & $\begin{array}{c}0.991 \\
(0.013)\end{array}$ \\
\hline Inn & & $\begin{array}{c}1.345 \\
(0.000)\end{array}$ & & $\begin{array}{c}1.203 \\
(0.000)\end{array}$ & & $\begin{array}{c}0.799 \\
(0.000) \\
\end{array}$ & $\begin{array}{c}0.763 \\
(0.000)\end{array}$ \\
\hline Shop & & $\begin{array}{c}0.121 \\
(0.701)\end{array}$ & & $\begin{array}{l}-0.140 \\
(0.622)\end{array}$ & & $\begin{array}{c}0.126 \\
(0.729)\end{array}$ & $\begin{array}{l}-0.120 \\
(0.742)\end{array}$ \\
\hline Cottage & & $\begin{array}{l}-0.890 \\
(0.000)\end{array}$ & & $\begin{array}{l}-0.472 \\
(0.006)\end{array}$ & & $\begin{array}{l}-0.977 \\
(0.000)\end{array}$ & $\begin{array}{l}-0.572 \\
(0.006)\end{array}$ \\
\hline Corner property & & $\begin{array}{l}-0.332 \\
(0.203)\end{array}$ & & $\begin{array}{l}-0.225 \\
(0.300)\end{array}$ & & $\begin{array}{l}-0.012 \\
(0.964)\end{array}$ & $\begin{array}{c}0.061 \\
(0.786)\end{array}$ \\
\hline Newly built & & $\begin{array}{l}-0.100 \\
(0.453)\end{array}$ & & $\begin{array}{l}-0.194 \\
(0.169)\end{array}$ & & $\begin{array}{c}0.066 \\
(0.728)\end{array}$ & $\begin{array}{l}-0.059 \\
(0.802)\end{array}$ \\
\hline Empty & & $\begin{array}{c}0.029 \\
(0.942)\end{array}$ & & $\begin{array}{c}0.046 \\
(0.891)\end{array}$ & & $\begin{array}{c}0.296 \\
(0.374)\end{array}$ & $\begin{array}{c}0.269 \\
(0.328)\end{array}$ \\
\hline Trade connection & & $\begin{array}{c}0.351 \\
(0.027) \\
\end{array}$ & & $\begin{array}{c}0.407 \\
(0.006) \\
\end{array}$ & & \begin{tabular}{|c|}
0.591 \\
$(0.000)$ \\
\end{tabular} & $\begin{array}{c}0.592 \\
(0.000) \\
\end{array}$ \\
\hline \multicolumn{8}{|l|}{ Ownership } \\
\hline Prior of Llanthony & & & $\begin{array}{l}-0.739 \\
(0.005)\end{array}$ & & $\begin{array}{l}-0.555 \\
(0.007)\end{array}$ & $\begin{array}{l}-0.939 \\
(0.000)\end{array}$ & $\begin{array}{l}-0.792 \\
(0.000)\end{array}$ \\
\hline Abbot of St. Peters & & & $\begin{array}{l}-0.353 \\
(0.140) \\
\end{array}$ & & $\begin{array}{l}-0.590 \\
(0.005)\end{array}$ & \begin{tabular}{|c|}
0.304 \\
$(0.121)$ \\
\end{tabular} & $\begin{array}{c}0.013 \\
(0.943) \\
\end{array}$ \\
\hline $\begin{array}{l}\text { Local religious } \\
\text { institutions }\end{array}$ & & & $\begin{array}{c}0.111 \\
(0.606)\end{array}$ & & $\begin{array}{l}-0.024 \\
(0.905)\end{array}$ & $\begin{array}{c}0.062 \\
(0.787)\end{array}$ & $\begin{array}{c}0.056 \\
(0.782)\end{array}$ \\
\hline Civic institutions & & & $\begin{array}{l}-0.439 \\
(0.014)\end{array}$ & & $\begin{array}{l}-0.537 \\
(0.014)\end{array}$ & $\begin{array}{l}-0.388 \\
(0.033)\end{array}$ & $\begin{array}{l}-0.294 \\
(0.191)\end{array}$ \\
\hline$R^{2}$ & 0.362 & 0.370 & 0.138 & 0.550 & 0.457 & 0.583 & 0.665 \\
\hline Adjusted $R^{2}$ & 0.343 & 0.316 & 0.102 & 0.495 & 0.417 & 0.527 & 0.607 \\
\hline$F$ statistic & $\begin{array}{l}18.764 \\
(0.000)\end{array}$ & $\begin{array}{c}6.893 \\
(0.000)\end{array}$ & $\begin{array}{c}3.921 \\
(0.005)\end{array}$ & $\begin{array}{l}36.530 \\
(0.000)\end{array}$ & $\begin{array}{l}11.434 \\
(0.000)\end{array}$ & $\begin{array}{l}10.488 \\
(0.000)\end{array}$ & $\begin{array}{l}11.501 \\
(0.000)\end{array}$ \\
\hline
\end{tabular}

Note: 103 observations. The significance level is indicated by a probability value where, by convention, 0.1 indicates weak significance, 0.05 significance, and 0.01 or below high significance. 
Table 3: Regression analysis of impact of location, ownership and type of property on landgavel

\begin{tabular}{|c|c|c|c|c|c|c|c|}
\hline Explanatory factor & 1 & 2 & 3 & 4 & 5 & 6 & 7 \\
\hline Constant & $\begin{array}{c}1.639 \\
(0.000) \\
\end{array}$ & $\begin{array}{c}1.586 \\
(0.000) \\
\end{array}$ & $\begin{array}{c}1.783 \\
(0.000) \\
\end{array}$ & $\begin{array}{c}1.565 \\
(0.000) \\
\end{array}$ & $\begin{array}{c}1.739 \\
(0.000) \\
\end{array}$ & $\begin{array}{c}1.642 \\
(0.000) \\
\end{array}$ & $\begin{array}{c}1.642 \\
(0.000) \\
\end{array}$ \\
\hline \multicolumn{8}{|l|}{ Location } \\
\hline Mercery \& Butchery & $\begin{array}{c}0.184 \\
(0.220)\end{array}$ & & & $\begin{array}{c}0.200 \\
(0.151)\end{array}$ & $\begin{array}{c}0.041 \\
(0.784)\end{array}$ & & $\begin{array}{c}0.114 \\
(0.442)\end{array}$ \\
\hline Westgate & $\begin{array}{c}0.302 \\
(0.163)\end{array}$ & & & $\begin{array}{c}0.256 \\
(0.200)\end{array}$ & $\begin{array}{c}0.308 \\
(0.145)\end{array}$ & & $\begin{array}{c}0.278 \\
(0.155)\end{array}$ \\
\hline Ebridge & $\begin{array}{c}0.227 \\
(0.193) \\
\end{array}$ & & & $\begin{array}{c}0.176 \\
(0.310) \\
\end{array}$ & $\begin{array}{c}0.128 \\
(0.455) \\
\end{array}$ & & $\begin{array}{c}0.107 \\
(0.545) \\
\end{array}$ \\
\hline Between the bridges & $\begin{array}{l}-0.535 \\
(0.020)\end{array}$ & & & $\begin{array}{l}-0.568 \\
(0.009)\end{array}$ & $\begin{array}{l}-0.604 \\
(0.010)\end{array}$ & & $\begin{array}{l}-0.616 \\
(0.007)\end{array}$ \\
\hline Central side lanes & $\begin{array}{c}0.067 \\
(0.703)\end{array}$ & & & $\begin{array}{c}0.010 \\
(0.954)\end{array}$ & $\begin{array}{l}-0.049 \\
(0.787)\end{array}$ & & $\begin{array}{l}-0.080 \\
(0.674)\end{array}$ \\
\hline Northgate & $\begin{array}{c}0.313 \\
(0.081) \\
\end{array}$ & & & $\begin{array}{c}0.278 \\
(0.077) \\
\end{array}$ & $\begin{array}{c}0.213 \\
(0.235) \\
\end{array}$ & & $\begin{array}{c}0.221 \\
(0.182) \\
\end{array}$ \\
\hline Between the gates & $\begin{array}{c}0,123 \\
(0.425)\end{array}$ & & & $\begin{array}{c}0.132 \\
(0.383)\end{array}$ & $\begin{array}{l}-0.010 \\
(0.945)\end{array}$ & & $\begin{array}{c}0.034 \\
(0.829)\end{array}$ \\
\hline Her Lane area & $\begin{array}{l}-0.288 \\
(0.088)\end{array}$ & & & $\begin{array}{l}-0.203 \\
(0.208) \\
\end{array}$ & $\begin{array}{l}-0.435 \\
(0.018) \\
\end{array}$ & & $\begin{array}{l}-0.314 \\
(0.093) \\
\end{array}$ \\
\hline Eastgate & $\begin{array}{c}0.556 \\
(0.007)\end{array}$ & & & $\begin{array}{c}0.447 \\
(0.031)\end{array}$ & $\begin{array}{c}0.423 \\
(0.039)\end{array}$ & & $\begin{array}{c}0.375 \\
(0.074)\end{array}$ \\
\hline Outside East Gate & $\begin{array}{l}-0.522 \\
(0.003)\end{array}$ & & & $\begin{array}{l}-0.388 \\
(0.026)\end{array}$ & $\begin{array}{l}-0.673 \\
(0.000)\end{array}$ & & $\begin{array}{l}-0.517 \\
(0.005)\end{array}$ \\
\hline Bareland & $\begin{array}{l}-0.128 \\
(0.519)\end{array}$ & & & $\begin{array}{c}0.239 \\
(0.196)\end{array}$ & $\begin{array}{l}-0.222 \\
(0.280)\end{array}$ & & $\begin{array}{c}0.142 \\
(0.490)\end{array}$ \\
\hline \multicolumn{8}{|l|}{ Type of property } \\
\hline Large tenement & & $\begin{array}{c}0.136 \\
(0.360) \\
\end{array}$ & & $\begin{array}{c}0.023 \\
(0.880) \\
\end{array}$ & & $\begin{array}{c}0.132 \\
(0.388) \\
\end{array}$ & $\begin{array}{c}0.025 \\
(0.875) \\
\end{array}$ \\
\hline Toft & & $\begin{array}{l}-0.139 \\
(0.484)\end{array}$ & & $\begin{array}{l}-0.073 \\
(0.637)\end{array}$ & & $\begin{array}{l}-0.101 \\
(0.610)\end{array}$ & $\begin{array}{l}-0.010 \\
(0.952)\end{array}$ \\
\hline Inn & & $\begin{array}{c}0.874 \\
(0.000)\end{array}$ & & $\begin{array}{c}0.856 \\
(0.000)\end{array}$ & & $\begin{array}{c}0.860 \\
(0.000)\end{array}$ & $\begin{array}{c}0.874 \\
(0.000)\end{array}$ \\
\hline Shop & & $\begin{array}{c}0.052 \\
(0.629)\end{array}$ & & $\begin{array}{l}-0.119 \\
(0.339)\end{array}$ & & $\begin{array}{c}0.018 \\
(0.868)\end{array}$ & $\begin{array}{l}-0.155 \\
(0.215)\end{array}$ \\
\hline Cottage & & $\begin{array}{c}0.013 \\
(0.942) \\
\end{array}$ & & $\begin{array}{c}0.108 \\
(0.398) \\
\end{array}$ & & $\begin{array}{r}0.046 \\
(0.740) \\
\end{array}$ & $\begin{array}{c}0.051 \\
(0.685) \\
\end{array}$ \\
\hline Land & & $\begin{array}{l}-0.417 \\
(0.000)\end{array}$ & & $\begin{array}{l}-0.395 \\
(0.002)\end{array}$ & & $\begin{array}{l}-0.387 \\
(0.002)\end{array}$ & $\begin{array}{l}-0.366 \\
(0.006)\end{array}$ \\
\hline Stable & & $\begin{array}{l}-0.204 \\
(0.447) \\
\end{array}$ & & $\begin{array}{l}-0.127 \\
(0.668) \\
\end{array}$ & & $\begin{array}{l}-0.144 \\
(0.566) \\
\end{array}$ & $\begin{array}{l}-0.030 \\
(0.913) \\
\end{array}$ \\
\hline Corner property & & $\begin{array}{c}0.199 \\
(0.215) \\
\end{array}$ & & $\begin{array}{c}0.128 \\
(0.432)\end{array}$ & & $\begin{array}{c}0.199 \\
(0.229)\end{array}$ & $\begin{array}{c}0.106 \\
(0.526)\end{array}$ \\
\hline Newly built & & -0.491 & & -0.487 & & -0.438 & -0.407 \\
\hline
\end{tabular}




\begin{tabular}{|l|l|l|l|l|l|l|l|}
\hline & & $(0.062)$ & & $(0.070)$ & & $(0.090)$ & $(0.121)$ \\
\hline Multiple residences & & 0.463 & & 0.411 & & 0.434 & 0.392 \\
& & $(0.002)$ & & $(0.012)$ & & $(0.003)$ & $(0.018)$ \\
\hline Parcel of land or & & 0.077 & & -0.029 & & 0.051 & -0.039 \\
tenement & & $(0.631)$ & & $(0.855)$ & & $(0.748)$ & $(0.811)$ \\
\hline Empty & & -0.035 & & -0.081 & & -0.012 & -0.078 \\
& & $(0.866)$ & & $(0.659)$ & & $(0.955)$ & $(0.656)$ \\
\hline Ruined or decayed & & -0.089 & & -0.182 & & -0.164 & -0.189 \\
& & $(0.577)$ & & $(0.327)$ & & $(0.351)$ & $(0.340)$ \\
\hline Trade connection & & 0.367 & & 0.296 & & 0.356 & 0.262 \\
& & $(0.000)$ & & $(0.007)$ & & $(0.000)$ & $(0.003)$ \\
\hline Professional \\
connection
\end{tabular}

Note: 378 observations. 
Table 4: The impact of landgavel on rent

\begin{tabular}{|c|c|}
\hline Explanatory factor & \\
\hline Constant & $\begin{array}{c}4.652 \\
(0.000)\end{array}$ \\
\hline Landgavel & $\begin{array}{l}-0.032 \\
(0.349)\end{array}$ \\
\hline \multicolumn{2}{|l|}{ Location } \\
\hline Mercery \& Butchery & $\begin{array}{c}0.878 \\
(0.007)\end{array}$ \\
\hline North-east & $\begin{array}{c}0.048 \\
(0.833)\end{array}$ \\
\hline \multicolumn{2}{|l|}{ Type of property } \\
\hline Large tenement & $\begin{array}{c}1.610 \\
(0.041)\end{array}$ \\
\hline Inn & $\begin{array}{c}1.567 \\
(0.049)\end{array}$ \\
\hline Corner property & $\begin{array}{l}-0.060 \\
(0.933)\end{array}$ \\
\hline Empty & $\begin{array}{c}0.371 \\
(0.259)\end{array}$ \\
\hline Trade connection & $\begin{array}{c}0.085 \\
(0.259) \\
\end{array}$ \\
\hline \multicolumn{2}{|l|}{ Ownership } \\
\hline Prior of Llanthony & $\begin{array}{c}0.584 \\
(0.009)\end{array}$ \\
\hline Abbot of St. Peters & $\begin{array}{c}0.584 \\
(0.081)\end{array}$ \\
\hline Local religious institutions & $\begin{array}{c}0.712 \\
(0.030)\end{array}$ \\
\hline Civic institutions & $\begin{array}{l}-0.406 \\
(0.030)\end{array}$ \\
\hline$R^{2}$ & 0.697 \\
\hline Adjusted $R^{2}$ & 0.523 \\
\hline$F$ statistic & $\begin{array}{c}4.019 \\
(0.003)\end{array}$ \\
\hline
\end{tabular}


Table 5: Spatial autocorrelation involving adjacent properties

\begin{tabular}{|l|l|l|l|}
\hline & Correlation & Probability value & $\begin{array}{l}\text { Number of pairs of } \\
\text { observations }\end{array}$ \\
\hline Rent & 0.365 & 0.086 & 23 \\
\hline Landgavel & 0.146 & 0.043 & 193 \\
\hline
\end{tabular}

